\title{
Nutritional Assessment For Patients With Hepatitis C Virus In The Compensated Stage By
} Hanan Mohamed Badran ${ }^{1}$, Soheir Mohamed Weheida ${ }^{2}$, Amany Mohamed Shebl Abd Ellateef ${ }^{3}$, Amira Ahmed Hassanein ${ }^{4}$ and Gamal El-Sayed Shiha ${ }^{5}$

1, 3,4 Medical Surgical Nursing Department, Faculty of Nursing-Mansoura University

2 Medical Surgical Nursing Department, Faculty of Nursing-Alexandria University

5 Hepatology and Gastroenterology, Faculty of Medicine - Mansoura University Hanan_mg2000@yahoo.com

\begin{abstract}
:
Nutritional assessment for hepatitis $\mathrm{C}$ virus is very important to prevent or treat malnutrition, overweight or deficiencies in specific nutrients and potentially hinders progression of the disease. It decreases the incidence of complications of hepatitis $\mathrm{C}$ virus. Assess dietary history, anthropometric measurement, and biochemical evaluation that interfere with nutritional well-being, and prognosis of hepatitis $\mathrm{C}$ virus patients. Moreover, it is the first step in planning the nutritional support for patients with hepatitis $\mathrm{C}$ virus. Therefore, the aim of this study was conducted for nutritional assessment of patient with hepatitis $\mathrm{C}$ virus in the compensated stage. Methods descriptive research design was utilized in the outpatient clinic of Liver Disease Unit at Main Mansoura Hospital. The data were collected from 60 adult patients of both sexes randomly selected according to inclusions criteria. Results $36.7 \%$ of the patients were in the age group of 41- years with mean age $39 \pm 9.43$. Females constituted $50 \%$ of the subject of the study. Mean and stander deviation of mid arm circumference is considered as $32.4 \pm 5.4$ while body mass index is considered as $28.1 \pm 4.2$. Conclusions anthropometric measurements play a key role in the nutritional assessment of patients with hepatitis $\mathrm{C}$ virus. It is very important to assess presence or absence of gastrointestinal problem and signs and symptoms of malnutrition that affects on daily intake.
\end{abstract}

Keywords: nutritional assessment, complication, hepatitis $\mathrm{C}$ virus.

\section{Introduction:}

nutritional well-being, and prognosis (American Dietetic Association, 2000).

Chronic hepatitis $\mathrm{C}$ virus is not a single disease, but it is a complex clinico-pathological syndrome with multiple causes, varying stages of necroinflammatory and sclerosing liver damage, different prognoses and responses to treatment (American Liver Foundation, 2013). Hepatitis $C$ virus may be different in various regions and various groups of the same community (Idrees et al., 2008). In the Middle East and Africa, prevalence is highest in Egypt $(18 \%)$ due to past practice of parenteral therapy for schistosomia in the second half of the last century which is responsible for 
Hanan Mohamed Badran.at.el.

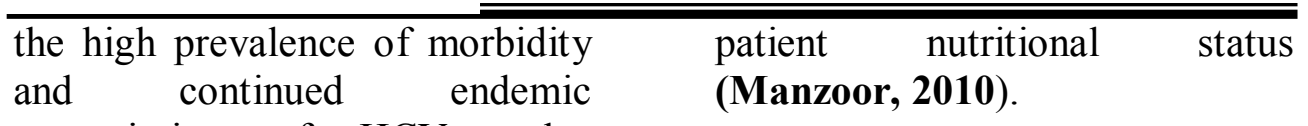
transmission of $\mathrm{HCV}$ today (Mohamoud, 2013).

Egypt has higher rates of $\mathrm{HCV}$ than neighboring countries as well as other countries in the world with comparable socioeconomic conditions and hygienic standards for invasive medical, dental, or paramedical procedures. Approximately 20\% of Egyptian blood donors are antiHCV positive (El-Zanaty and Way, 2009 and Azab et al., 2011). Moreover, the burden of disease is greatest in developing countries: the highest reported prevalence is in Egypt (22\%), Pakistan (4.8\%), and China $(3.2 \%) \quad$ (World Health Organization, 2013). According to the statistical record of Outpatient Liver Disease Unit in the Mansoura General Hospital the total number of viral hepatitis C patients up till February 2013 was (12000).

Hepatitis $\mathrm{C}$ virus has emerged as a major public health problem throughout the world. It is a cause of significant morbidity and mortality in human being, The $\mathrm{HCV}$ are a leading cause of cirrhosis, a common cause of hepatocellular carcinoma (HCC) the leading cause of liver transplantation, malnutrition. All of these complications affect on

Assessment of nutritional status is very important for early identification of nutrition-related problems and assesses severity of any condition that affects disease progression. Also it is vital for successful treatment and prevention of more serious complications. A complete nutrition assessment includes a review of medical history and risk factors, medication profile, and nutritional profile that including appropriate anthropometrics, body composition, evaluation of dietary intake, biochemical evaluation, notation of psychosocial and economic conditions, changes in routine, and symptoms that interfere with nutritional wellbeing, and prognosis (American Dietetic Association, 2000).

\section{Aim of the study}

The study aim is to assess the nutritional status of patients with hepatitis $\mathrm{C}$ virus in the compensated stage.

\section{Subject and Method}

\section{Materials:}

\section{Research design:}

Descriptive research design was utilized in study. 
Nutritional Assessment for Patients with Hepatitis etc....

\section{Setting:}

This study was conducted in the outpatient clinic of Liver Disease Unit at Mansoura General Hospital.

\section{Subjects:}

A convenient sample of 60 adult patients of both sexes with the diagnosis of hepatitis $\mathrm{C}$ virus within three months.

Criteria for selection of the subjects:

- Adult (21-60) years old.

- Conscious patient.

- Compensated degree of liver cirrhosis.

- Free from any associated chronic disease such as cardiac, renal, and diabetes mellitus.

\section{Tool of the study}

Nutritional assessment sheet; structure interview schedule:

It was developed by the researcher for collection of required base line data and to assess patient nutritional status based on review of relevant literature.

Part I: Biosociodemographic and medical data sheet:

It was used for collection of personal and medical data that includes: (1) sociodemographic characteristics as age, sex, level of education, occupation, and marital status. (2) Medical data as date of admission, diagnosis, duration of disease, previous hospitalization, and past and present medical history.

Part II: Past dietary history

It was included of patient dietary history such as weight loss during the previous 6 months, eating habits, eating and drinking likes and dislikes, food allergies, changes in dietary intake, number of meal per day, feeling of discomfort before and after meals, gastrointestinal symptoms, and the presence of presacral or pedal edema (Cave, 2007).

Part III: 3-4 day dietary recall:

This part used as daily dietary intake for the past 3 days to provide a more complete and accurate dietary evaluation. It was taken from the patient or close relatives to the patients. It includes the daily ingestion of calories, protein, fats, vitamins, and minerals in household measurements (Bunout, 2005).

Part IV: Anthropometric measurements:-

Height and weight: was taken (Schulze 2013).

Mid arm circumference (MAC) and Triceps skin fold thickness (TSF):- 
They were used to assess the skeletal muscle mass and fat storage. Both are measured at the same site, with the patient's right arm in a relaxed position. The average mid arm circumference is about, 22.3-30.6 (cm), while TSF, is about $4-25(\mathrm{~mm})$. Three measurements were taken for both TST and MAC, with average values calculated and recorded (John, 2007).

Mid-arm muscle

circumference (MAMC):-

It was used to measure muscle protein mass that calculated from mid arm circumference (MAC) and triceps skin fold thickness (TSF) using a standard formula: MAMC $(\mathrm{cm})=$ MAC $(\mathrm{cm})-[0.314 \times$ TSFT $(\mathrm{mm})]$. Adults MAMC ranged from 18.5-25.5 (cm). Measures below $15(\mathrm{~cm})$ indicate protein depletion. Findings compared against normal values (Alhamdan, 2004).

Body mass index (BMI):-

It was calculated by dividing the weight in kilograms by the square of the height in meters $(\mathrm{kg} / \mathrm{m} 2)$. Standards classify BMI into several categories; below 18.5 /underweight, 18.5-24.9 / normal, 25-29.9 / overweight, 3039.9 / obese, and above 40 / very obese. Findings compared against normal values (Johnstone C, 2006).
Abdominal circumference: -

Normal values are $89.54 \pm 7.53$.

Findings compared against normal values (Ali, 2011).

Part V: Physical signs of malnutrition:

It was used for assessment of body parts that indicate the presence of malnutrition e.g. condition of the skin, eyes, mouth, hair, nails and vital signs. Findings compared against normal values (David, 2008 and Miei, 2010).

\section{Methods:}

A permission to carry out the study was obtained from the responsible authorities of the Outpatient clinic of Liver Disease in the Mansoura General Hospital. An informed written consent was taken from the patients before inclusion in the study, after explanation the purpose of the study.

All patients were assessed immediately on the first visit to the outpatient clinic of liver disease of Mansoura General Hospital to collect base line data.

Anthropometric measurements were assessed for all patients with hepatitis $\mathrm{C}$ virus.

All patients with hepatitis $C$ virus were assessed for their laboratory finding. Findings compared against normal values. 
Nutritional Assessment for Patients with Hepatitis etc....

\section{Results:}

The data collected were analyzed statistically and the results are categorized into 5 main parts which are: sociodemographic characteristics, signs and symptoms of malnutrition, dietary history, anthropometric measurements, and laboratory findings.

Table 1 revealed that, $36.7 \%$ of the patients were in the age group of 41- years with mean age of $39 \pm 9.43$. Females constituted $50 \%$ of the subject. Also males constituted half of the study subject. As regard to marital status the majority of patients (86.7) were married. Concerning level of education, the illiterate and university education were constituted approximately $26.7 \%$ of patients in the subject of the study.

In addition, private occupation was found to be the most prevailing job with approximately $40.0 \%$. As regard to the family member it was noticed that, the majority of patient had $4-6$ member in his family. As well as approximately $(70.0 \%)$ living with their family. In relation to activity, the majority of patients were performing moderate activity.

Table 2 represents that, among subject of the study $28.3 \%$ suffered from weight loss compared to $21.7 \%$ hand weight gain in the last 6 months. Furthermore the result of the present study reveals that, the most common previous eating disorders are anorexia and nausea (43.3 and 38.3). The majority of patients (96.7) have no allergy to food and 86.7 taken 2-3 meals per day. Also this table illustrates that, feeling of discomfort before meals had represented $8.3 \%$ by the study subject while feeling of discomfort after meals represented by $30 \%$. Moreover, $91.7 \%$ of subject did not suffered from any signs and symptoms of malnutrition.

Table 3 illustrated that, at baseline $8.3 \%$ of study group suffered from signs and symptoms of malnutrition compared to $6.7 \%$ of control group. After one month and at the beginning of the treatment this percentage become $0.0 \%$ in the studied group and, 6.7 $\%$ in control group. The significant difference was considered insignificant.

As regard to anthropometric measurements table 4 revealed that, mean and stander deviation for weight is considered as $84.9 \pm$ 12, while mid arm circumference and mid-arm muscle circumference are represented by (32.4 \pm 5.4 and $27.5 \pm 5.6)$. Moreover, body mass index represent $(28.1 \pm 4.2)$

As regard to laboratory findings table 4 reveals that, liver function 
test and complete blood count of the subject of the study were within normal range. While mean and stander deviation for serum bilirubin and albumin were $(0.731$

\section{Results:}

Table (1): Percentage distribution of patients suffering from hepatitis $\mathrm{C}$ virus according to Sociodemographic characteristics.

\begin{tabular}{|c|c|c|}
\hline \multicolumn{3}{|c|}{ Sociodemographic characteristics } \\
\hline Age group & $\mathbf{N}$ & $\%$ \\
\hline $21-$ & 13 & 21.6 \\
\hline $31-$ & 19 & 31.7 \\
\hline $41-$ & 22 & 36.7 \\
\hline $51-60$ & 6 & 10.0 \\
\hline $\begin{array}{c}\text { Range } \\
\text { Mean } \pm \text { SD }\end{array}$ & \multicolumn{2}{|c|}{$\begin{array}{c}21-57 \\
39 \pm 9.43\end{array}$} \\
\hline \multicolumn{3}{|l|}{ Gender } \\
\hline Male & 30 & 50.0 \\
\hline Female & 30 & 50.0 \\
\hline \multicolumn{3}{|c|}{ Level of education } \\
\hline Illiterate & 16 & 26.7 \\
\hline Read \&write & 14 & 23.3 \\
\hline Secondary & 14 & 23.3 \\
\hline Unversity & 16 & 26.7 \\
\hline \multicolumn{3}{|l|}{ Marital status } \\
\hline Single & 6 & 10.0 \\
\hline Married & 52 & 86.7 \\
\hline Widow & 1 & 1.7 \\
\hline Divored & 1 & 1.7 \\
\hline \multicolumn{3}{|l|}{ Occupation } \\
\hline Governmental & 13 & 21.7 \\
\hline Private & 24 & 40.0 \\
\hline Student & 3 & 5.0 \\
\hline House wife & 20 & 33.3 \\
\hline Reteirment & 0.0 & 0.0 \\
\hline \multicolumn{3}{|l|}{ Income } \\
\hline Low & 44 & 73.3 \\
\hline Moderate & 16 & 26.7 \\
\hline High & 0.0 & 0.0 \\
\hline
\end{tabular}

\pm 0.196 and $4.04 \pm 0.4)$.

Moreover, hemoglobin level and red blood cells represented (13 \pm 1.8 and $4.689 \pm 0.759$ ) 
Nutritional Assessment for Patients with Hepatitis etc....

Table (1) Cont:
\begin{tabular}{|c|c|c|}
\hline \multicolumn{3}{|c|}{ Sociodemographic Data } \\
\hline Family member & N & \% \\
\hline $1-3$ & 17 & 28.3 \\
\hline $4-6$ & 35 & 58.3 \\
\hline 7 or more & 8 & 13.3 \\
\hline Living status & 3 & 5.0 \\
\hline Alone & 42 & 70.0 \\
\hline With family & 15 & 25.0 \\
\hline With other & & \\
\hline
\end{tabular}

Table (2): Percentage distribution of patients suffering from viral hepatitis $\mathrm{C}$ according to their Dietaryhistory:

\begin{tabular}{|c|c|c|c|}
\hline \multicolumn{2}{|c|}{ Dietaryhistory } & $\mathbf{N}$ & $\%$ \\
\hline \multirow[t]{2}{*}{ Weight loss } & Yes & 17 & 28.3 \\
\hline & No & 43 & 71.7 \\
\hline \multirow[t]{2}{*}{ Weight gain } & Yes & 13 & 21.7 \\
\hline & No & 47 & 78.3 \\
\hline \multirow{6}{*}{ Previous eating disorders } & Anorexia & 21 & 43.3 \\
\hline & Nausea & 23 & 38.3 \\
\hline & Vomiting & 9 & 15.0 \\
\hline & Diarrhea & 2 & 3.3 \\
\hline & Constipation & 3 & 0.5 \\
\hline & heartburn & 15 & 25.0 \\
\hline \multirow[t]{2}{*}{ Food allergies } & Yes & 2 & 3.3 \\
\hline & No & 58 & 96.7 \\
\hline \multirow[t]{3}{*}{ Number of meal per day } & $2-3$ & 52 & 86.7 \\
\hline & $3-4$ & 7 & 11.7 \\
\hline & $4-5$ & 1 & 1.7 \\
\hline \multirow{2}{*}{$\begin{array}{r}\text { Feeling of discomfort } \\
\text { before meals }\end{array}$} & Yes & 6 & 8.3 \\
\hline & No & 54 & 91.7 \\
\hline \multirow{2}{*}{$\begin{array}{r}\text { Feeling of discomfort } \\
\text { after meals }\end{array}$} & Yes & 18 & 30.0 \\
\hline & No & 42 & 70.0 \\
\hline \multirow{2}{*}{$\begin{array}{r}\text { Signs and symptoms of } \\
\text { malnutrition }\end{array}$} & Yes & 5 & 8.3 \\
\hline & No & 55 & 91.7 \\
\hline
\end{tabular}


Table (3): Percentage distribution of patients suffering from viral hepatitis $\mathrm{C}$ according to their dietary history and presence or absence of malnutrition:

\begin{tabular}{|c|c|c|c|c|c|c|c|}
\hline \multirow{3}{*}{ Items } & & \multicolumn{4}{|c|}{ Groups } & \multirow{3}{*}{$\mathbf{X}^{2}$} & \multirow{3}{*}{$\mathbf{P}$} \\
\hline & & \multicolumn{2}{|c|}{$\begin{array}{l}\text { Study group } \\
\qquad \mathbf{N}=\mathbf{6 0}\end{array}$} & \multicolumn{2}{|c|}{$\begin{array}{l}\text { Control group } \\
\qquad \begin{array}{l}\mathrm{N}=60 \\
\end{array}\end{array}$} & & \\
\hline & & $\mathbf{N}$ & $\%$ & $\mathbf{N}$ & $\%$ & & \\
\hline \multirow[t]{2}{*}{ On admission } & Yes & 5 & 8.3 & 4 & 6.7 & \multirow[t]{2}{*}{0.12} & \multirow[t]{2}{*}{$>0.05$} \\
\hline & No & 55 & 91.7 & 56 & 93.3 & & \\
\hline \multirow[t]{2}{*}{ After one month } & Yes & 0.0 & 0.0 & 3 & 5.0 & \multirow[t]{2}{*}{ FE test } & \multirow[t]{2}{*}{$>0.05$} \\
\hline & No & 60 & 100 & 57 & 95.0 & & \\
\hline \multirow[t]{2}{*}{ Pretreatment } & Yes & 0.0 & 0.0 & 4 & 6.7 & \multirow[t]{2}{*}{ FE test } & \multirow[t]{2}{*}{$>0.05$} \\
\hline & No & 60 & 100 & 59 & 93.3 & & \\
\hline
\end{tabular}


Nutritional Assessment for Patients with Hepatitis etc....

Table (4): Mean and stander deviation of patients suffering from hepatitis $C$ virus according to anthropometric measurements and laboratory findings:

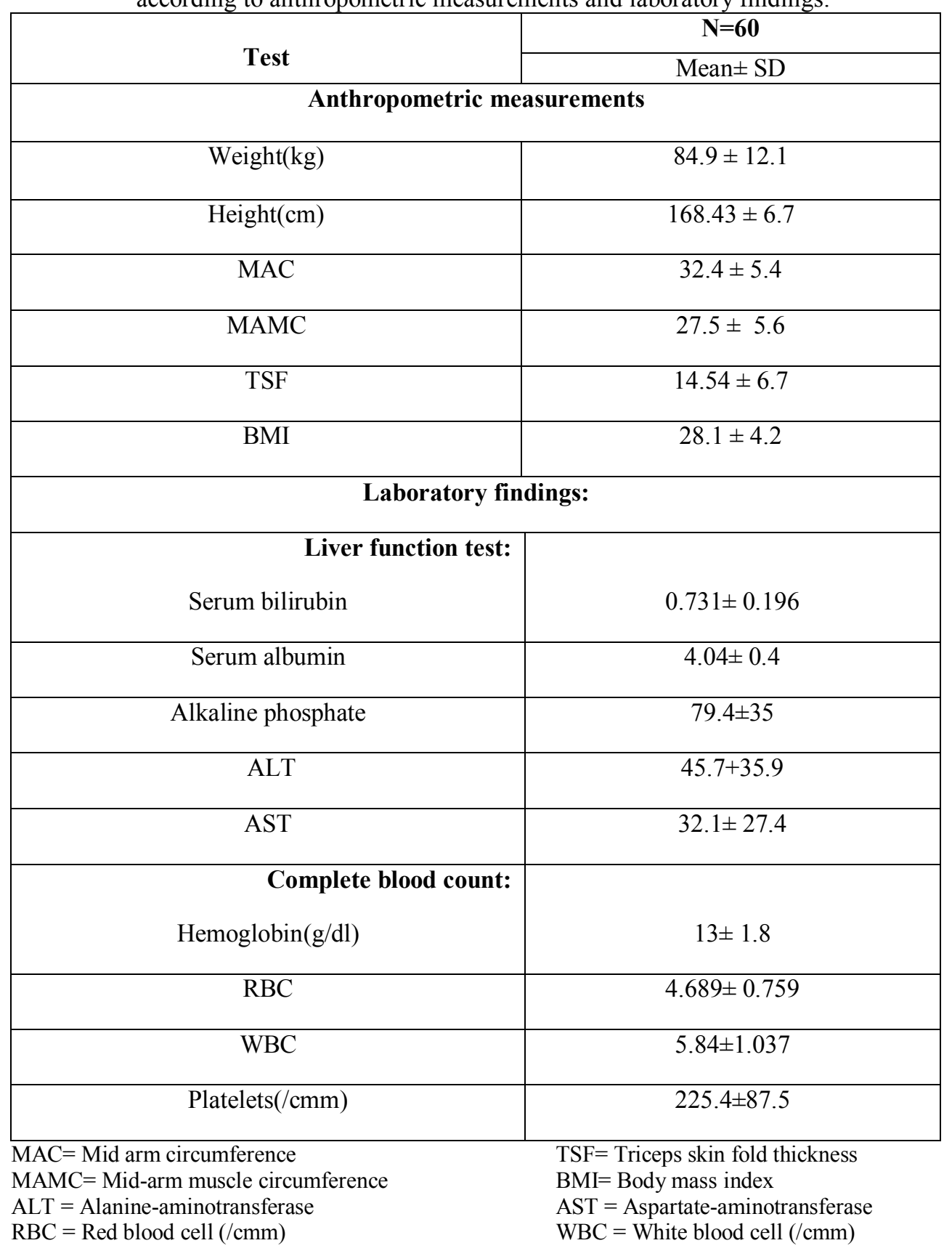


Hanan Mohamed Badran..at.el.

\section{Discussion:}

As regards to age, the present study findings revealed that, more than half of the study and control groups were in middle adult. This result is in agreement with National Institutes of Health (2002) illustrated that, many HCV infected persons are in the age group of 30 to 39 and may become affected by complications of the disease over the next 10 to 20 years. On the same line the present result come in accordance with Medhat (2001) who added that, Egypt has the highest prevalence rates of $\mathrm{HCV}$ in the world over the age of 30 years. These findings also were in disagreement with Roberts (2010) who mentioned that, liver disease can take hundreds of forms. It affects men, women, and children regardless of age, nationality, lifestyle or economic circumstances.

In relation to gender the findings of the present study represented that, females constituted half patients of the study this may be attributed to female are more exposed to blood born disease due to pregnancy, delivery and household activities which make them at high risk of hepatitis $\mathrm{C}$ infection. This result in the same line with, Iversen (2010) who illustrated that, women are at greater risk than men about hepatitis $\mathrm{C}$ virus infection during the early years through higher rates of receptive sharing of needles and syringes and/or ancillary equipment.

The result of the present study is contradicting with Muhammad (2005) who clarified that, the prevalence of $\mathrm{HCV}$ was higher in males $(17.30 \%)$ due to exposure to numerous risk factors as compared to females $(12.68 \%)$ which is in conformity with another local study. According to our cultural environment, females are only negligibly exposed to some of the risk factors e.g. tattooing, injection drug use, barbers etc.

As regard to level of education, the result of the present study showed that, the majority of the subject had in university and illiterate level. In fact this may be related to that, most of the study group came from rural area with low socioeconomic level, interested in manual and farmer work. This is in harmony with; Rajesh (2012) who reported that, the prevalence of hepatitis $\mathrm{C}$ virus was more in illiterate subjects and increased with decreasing monthly income. Also Mustafa et al. (2001) reported that, the risk factors for $\mathrm{HCV}$ infection in a rural village in the Nile Delta with a high prevalence of antibodies to $\mathrm{HCV}$ (anti-HCV). High prevalence of $\mathrm{HCV}$ was found among unemployment, poor education, 
Nutritional Assessment for Patients with Hepatitis etc....

and mental health issues (Hahn et al., 2002).

The present study illustrated that large number of the study subject were housewives, this may be related to half of the study subject are females and may have sedentary life style or low activity level. Moreover private occupation accounted for the highest percentage of the study finding. This may be related to the majority of the study subject had low socioeconomic level, do not work in accordance to their educational level, and decreased chance of work in governmental jobs but they are working in private manual work. This finding was in disagreement with Dore et al. (2001) who showed that, community or household transmission of $\mathrm{HCV}$ is considered rare.

This result comes in consistent with Strickland (2006) who agreed that, epidemiological studies reported a high prevalence and incidence of $\mathrm{HCV}$, particularly within families in rural areas who had endemic for schistosomiasis. This in harmony with Frank et al. (2000) who stressed that, the very high prevalence of HCV infection in the adult population of rural areas of Egypt, were particularly in men living in villages where schistosomiasis is endemic and it occurs as a result of extensive mass-control campaigns using parenteral tartar emetic conducted from the 1950s up until 1982.

As regard to the dietary history the finding of the present study reflected that, the majority of the study had suffered from anorexia, nausea, heart burn, and feeling of discomfort after meals. This in harmony with Nutrition Care Manual (2010) report that, decreased intake may occur from fatigue, anorexia, nausea/ vomiting, and early satiety. Moreover, decreased intake and malnutrition are often associated with infection. In addition, the anorexia, nausea and vomiting associated with $\mathrm{HCV}$ can lead to poor dietary intake and further potential for malnutrition (Amodio et al., 2001).

It was observed that the minority of the study groups had experience signs and symptoms of malnutrition. This was in the same line with Alter et al. (2004) who found that, because symptoms are generally absent in individuals with chronic HCV infection, recognition of infection requires risk factor screening, which should be done whenever it is possible to link with appropriate $\mathrm{HCV}$ testing and counseling. Moreover the finding of the present study reveals that, the majority of patient not experiencing signs and symptoms of malnutrition. This result in harmony with, Teran and 
Hanan Mohamed Badran..at.el.

\begin{tabular}{lllr}
\hline McCullough & (2001) who & estimated needs, biochemical \\
mentioned that malnutrition & evaluation, notation of \\
commonly occurs with progressive & psychosocial and economic \\
liver disease and has been found to & conditions, changes in routine, \\
have a significant negative impact & symptoms that interfere with \\
on morbidity and mortality. & nutritional well-being, and \\
$\quad$ In addition, most patients will & prognosis.
\end{tabular}
pass on to chronic hepatitis $\mathrm{C}$ without knowing they have it and they are at significant risk of cirrhosis and hepatocellular carcinoma (HCC). Many people will have no symptoms, while others will feel unwell to varying degrees. Most people will remain well and without symptoms for a number of years and this makes the infection difficult to recognize. Disease progression and severity is very variable and patients may not become symptomatic until their liver disease is advanced (Ford, 2010).

\section{Regarding anthropometrics}

measurement, the result of the present study showed that, it is very important to assess anthropometrics measurement as a base line data throughout the study. This finding in accordance with American Dietetic Association (2000) reports that, a complete nutrition assessment includes a review of medical history and risk factors, medication profile, nutritional profile including appropriate anthropometrics, body composition, evaluation of dietary intake, and comparison with

Similarly, Subjective global assessment when compared to anthropometric data shows an $77 \%$ may prove to be a useful tool for screening of malnutrition but this approach fails to provide a sensitive quantitative nutritional measure change (Fried et al., 2002).

One of the limitations in providing dietary advice is that individuals have very different tolerances, requirements, likes and dislikes for certain foods. Therefore, assessment and modification of the dietary intake may be necessary. It is useful to note reactions to foods to get an idea of individual tolerance. If fatty or rich foods create nausea they are obviously shows that it was not tolerated well and so best to be avoided. A balanced diet is important for general health (Cutler, 2014).

Regarding to laboratory investigation the finding of the present study reflected that, there is stability in most of liver function test and complete blood count within the normal range. In fact this is very important to take base line 
Nutritional Assessment for Patients with Hepatitis etc....

\begin{tabular}{l}
\hline laboratory investigation and \\
maintain it stable within normal \\
range before regimen of PEG-IFN \\
and RBV because it leads to \\
multiple side effects, CBC and \\
nutrition alteration one of them.
\end{tabular}

This in harmony with Sulkowski et al. (2011) who reveals that, monitoring hematologic and clinical chemistry laboratories must be obtained at as baseline; to detect anemia or any other abnormalities and prevent treatment failures.

The finding of the present study consistent with, McHutchison et al. (2009) who clarified that, some but not all, studies also suggest that the increased body weight has a negative impact on the probability of sustained virologic response (SVR) to therapy with PEG-IFN and RBV.

\section{Conclusion:}

The present study concluded that the majority of subjects suffer from gastrointestinal problem such as anorexia and nausea that affects on daily intake not suffering from signs and symptoms of malnutrition. Mean and stander deviation of mid arm circumference is considered above normal range while body mass index is considered as overweight. So the present study provide evidence base that nutritional assessment are very important to determine factors that interfere with nutritional wellbeing, and prognosis of hepatitis $\mathrm{C}$ virus. Moreover, the hepatitis $\mathrm{C}$ virus is considered as silent endemic disease that leads to long term problems within long period of the time without and signs and symptoms. Also, it is the first step in planning the nutritional support for patients with hepatitis $C$ virus.

\section{Recommendations:}

- In-service education program for nurses to equip them with the most resent methods of nutritional assessment

- A manual guideline about the nutritional assessment should be available in any liver disease unit.

- The nutritional assessment should be performed before starting antiviral treatment.

\section{References}

1. Alhamdan A (2004): Nutritional Status of Saudi Males Living in the Riyadh Nursing Home. J Clin Nutr; 13 (4): $372-76$.

2. Ali I, Siddique L, Rehman L, Khan N, Khan F, and Zahoor A (2011): Prevalence of HCV among the high risk groups in Khyber Pakhtunkhwa. Virology Journal; 8:296. Available at: http://www.virologyj.com/con tent $/ 8 / 1 / 296$. Accessed on 2/5/2013. 
3. Alter MJ, Seeff LB, Bacon BR, Thomas DL, Rigsby MO, and Bisceglie AM (2004): Testing for hepatitis $C$ virus should be routine for persons at increased risk for infection. Ann Intern Med; 141:715-17.

\section{American}

Dietetic

Association of Canada

(2000): Nutrition Intervention in the Care of Persons with hepatitis C virus; 90:1138-40. Available at: www.journals.elsevierhealth.c om/yjada/references Accessed on $20 / 8 / 2012$.

\section{American Liver Foundation}

(2013): Hepatitis C Diagnosis, Treatment \& Support. Available at: hepc.liverfoundation.org/treat ment/...hepatitis-c-treatment. Accessed on 14/2/2013.

6. Amodio P, Caregaro L, and Patteno E (2001): Vegetarian diets in hepatic encephalopathy: facts or fantasies. Dig Liver Dis; 33(6):492.500.

7. Available at: consensus.nih.gov/cons/116/H epc091202.pdf.Accessed on 2/5/2013.

8. Azab N, Abd El Kariem H, Mowafi T, Fouad F, and Awad M (2011): Blood RasAssociation Domain Family 1
A Gene Methylation Status In

Some Liver Diseases Life

Science Journal; $8(2)$.

Available at:

http://www.lifesciencesite.co

m. Accessed at $8 \backslash 9 \backslash 2012$.

9. Bunout D (2005): Nutritional Status of Alcoholic Patients. American journal of clinical nutrition. Available at http://cdaar.tufts.edu/protocols /Handgrip.pdf. Accessed on 78-2011.

10. Cave M. (2007): Nonalcoholic Fatty Liver Disease: Predisposing Factors and the Role of Nutrition. JNutrBiochem; 18(3):184-95. Review. Available at http://www.ncbi.nlm.nih.gov/p ubmed/17296492. Accessed on $1 / 7 / 2011$.

11. Cutler N (2014): Hepatitis $C$ Dietary; what to consume or avoid with Hepatitis C. Available at http://www.hepatitiscentral.co $\mathrm{m} / \mathrm{mt} /$ archives/2014/01/4hepatitis-c-dietary-myths.html. Accessed on 5/4/2013.

12. David R. (2008): Physical Examination. Available at http://www.rxkinetics.com/tpn tutorial/1_3.html. Accessed on 22/7/201‥

13. Dore G, Grulich A, Kidd M, McCoy R, Mijch A and Strasser S (2001): HIV/Viral 
Nutritional Assessment for Patients with Hepatitis etc....

hepatitis - a guide for primary care, Australasian Society for HIV Medicine. Available at: http://www.ashm.org.au.

Accessed on 22/7/2011.

14. El-Zanaty F, and Way A (2009): Egypt Demographic and Health Survey Egyptian: Ministry of Health. Cairo: ElZanaty and Associates, and MacroInternational.

15. Ford C, Halliday K, Foster G, Gore G, Jack K, Rowan $\mathrm{N}$, Saville $\mathrm{S}$, Thomson $\mathrm{B}$, and Willott $S$ (2010): Guidance for the prevention, testing, treatment, management for hepatitis $\mathrm{C}$ in primary care. Available at: www.smmgp.org.uk and www.rcgp.org.uk. Accessed on $8 / 12 / 2013$.

16. Frank C, Mohamed MK, Strickland GT, Lavanchy D, Arthur RR, Magder LS, and El Khoby T (2000): The role of parenteral antischistosomal therapy in the spread of hepatitis $\mathrm{C}$ virus in Egypt. Lancet; 355:887-91.

17. Fried MW, Shiffman ML, Reddy KR, Smith C, Marinos G, and Goncales FL (2002): Peginterferon alfa2a plus ribavirin for chronic hepatitis $\mathrm{C}$ virusinfection. $\mathrm{N}$ Engl J Med; 347:975-82.
18. Hahn JA, Page-Shafer $K$, and Lum PJ (2002): Hepatitis $\mathrm{C}$ virus seroconversion among young injection drug users: relationships and risks. $\mathrm{J}$ Infect Dis; 186:1558-64.

19. Idrees M, La A, Naseem M, and Khalid M (2008): High prevalence of hepatitis $C$ virus infection in the largest province of Pakistan. J.Dig.Dis; 9:95-103.

20. Iversen J, Wand $H$, Gonnermann A, and Maher L (2010): Gender differences in hepatitis $\mathrm{C}$ antibody prevalence and risk behaviors amongst people who inject drugs in Australia. nt J Drug Policy. Nov; 21(6):471-6.

21. John E (2007): Nutritional Disorders. Available at: http://www.merckmanuals.co $\mathrm{m} /$ professional $/ \mathrm{sec} 01 / \mathrm{ch} 002 / \mathrm{c}$ h002a.html Accessed on 20/9/ 2011.

22. Johnstone $\mathbf{C}$, Hendry $\mathbf{C}$, and Aroln M (2006): Nurses' Role in Nutritional Assessment and Screening; $\quad$ 102(49):28 available at http://www.nursingtimes.net/S earchResults.aspx?qsearch $=1$ \&qkeyword $=$ Nurses $\% 27+$ role + in + nutritional + assessment $+a$ nd+screening++Part+one+of+a+two- 
Hanan Mohamed Badran..at.el.

part+series\&x47\&y13.Access ed on $6 / 8 / 2011$.

23. Manzoor S (2010): Role of P2x Receptors in Hepatitis C Virus Induced Liver Cirrhosis: National Center of Excellence in Molecular Biology University of the Punjab Lahore. Available at: http: /prr.hec.gov.pk/Thesis/1114S. pdf. Accessed on 18/7/2013.

24. McHutchison JG, Lawitz EJ, and Shiffman ML (2009): Peginterferon alfa- $2 b$ or $2 \mathrm{a}$ with ribavirin for treatment of hepatitis $\mathrm{C}$ infection. $\mathrm{N}$ Engl $\mathrm{J}$ Med; 361:580-93.

25. Medhat a, Faris R, Shouman a, Gadallah M, Mohamed S. EL-Sharkawy, Edelman R, Grumbach K, Malla, and John D (2001): Hepatitis C and cirrhosis liver disease in the Nile delta of Egypt. Am. J. Trop. Med. Hyg, 64(3, 4), 147-153.

26. Mieilg S, Khean L. (2010): Anthropometric, Biochemical and Clinical Assessment of Malnutrition in Malaysian Patients with Advanced Cirrhosis. Nutrition Journal, 9:27.

27. Mohamoud YA, Mumtaz GR, Riome S, Miller D, and Abu-Raddad LJ (2013): The epidemiology of hepatitis C virus in Egypt: a systematic review and data synthesis. BMC Infect Dis. Jun; 24 (13):288. Available at: http://www.ncbi.nlm.nih.gov/p ubmed/23799878. Accessed on $2 / 7 / 2012$.

28. Mostafa $H$, Mostafa $K$, Mohamed G, Salah M, Nabiel N, Mihhail N, Adel aziz $F$, and Agida W (2001): Hepatitis C Virus Infection in a Community in the Nile Delta: Risk Factors for Seropositivity. HEPATOLOGY; 5(33), 1.

29. Muhammad N (2005): Frequency of hepatitis C. J Coll Physicians Surg Pak; 15:11-4.

30. National Institutes of Health (2002): Consensus Development Conference Statement Management of Hepatitis C: Hepatology; 36 (1):S3-20.

31. Rajesh N, Sadiq K, and AlMohani S (2012): Hepatitis Research and Treatment. Volume, Article ID 689726, 4 available at: http://dx.doi.org/10.1155/2012 /689726. Accessed on 2/5/2013.

32. Robert $B$ and Frank $J$ (2011): Treatment of chronic hepatitis $\mathrm{C}$ in active drug users. New England Journal of 
Nutritional Assessment for Patients with Hepatitis etc....

Medicine; 345(3):215-7.

Available at:

http://familydoctor.org/family

doctor/en/diseases-

conditions/hepatitis-c.html.

Accessed on 12/3/2013.

33. Robert S (2010): Factors Affecting Nutrition:

Development, Gender,

Ethnicity and Culture, Beliefs

about Food, and Personal

Preferences available at:

http://nutrition1.knoji.com/fact

ors-affecting-nutrition-

development-gender-ethnicity-

and-culture-beliefs-about-

food-and-personal-

preferences/. Accessed on 12/5/2013.

34. Schulze K (2013):

assessment of nutritional status. Available

at

http://www.jhsph.edu/courses/

course/222.642/01/2013/1759

9/ Accessed at 28\12\2012.
35. Strickland GT (2006): Liver disease in Egypt: Hepatitis C superseded schistosomiasis as a result of iatrogenic and Biological factors. Hepatology 43: 915-922.

36. Sulkowski MS, Cooper C, and Hunyady B (2011): Management of adverse effects of Peg-IFN and ribavirin therapy for hepatitis C. Gastroenterol Hepatol; 8:212-23.

37. Teran FC, and McCullough AF (2001): The Science and Practice of Nutrition Support:
A Case-Based Core

Curriculum. American Society for Parenteral and Enteral Nutrition. Dubuque, Iowa: Kendall/Hunt Publishing Company: 537.552.

38. World Health Organization (2013): epidemiology of HCV. Available at: http://www.who.int/mediacent re/factsheets/fs164/en. A ccessed on $2 / 4 / 2013$. 